\title{
Urgences
}

\section{Réconciliations (extrait)}

\section{Line Arsenault}

Numéro 4, 2e trimestre 1982

URI : https://id.erudit.org/iderudit/025057ar

DOI : https://doi.org/10.7202/025057ar

Aller au sommaire du numéro

Éditeur(s)

Urgences

ISSN

0226-9554 (imprimé)

1927-3924 (numérique)

Découvrir la revue

Citer ce document

Arsenault, L. (1982). Réconciliations (extrait). Urgences, (4), 35-40.

https://doi.org/10.7202/025057ar

Ce document est protégé par la loi sur le droit d'auteur. L'utilisation des services d'Érudit (y compris la reproduction) est assujettie à sa politique d'utilisation que vous pouvez consulter en ligne.

https://apropos.erudit.org/fr/usagers/politique-dutilisation/
Cet article est diffusé et préservé par Érudit.

Érudit est un consortium interuniversitaire sans but lucratif composé de l’Université de Montréal, l'Université Laval et l'Université du Québec à Montréal. Il a pour mission la promotion et la valorisation de la recherche. https://www.erudit.org/fr/ 
LINE ARSENAULT

\section{Réconciliations}

(Extrait) 
Je me suis étendue sur mon lit nue,

dans une grande chemise pâle faite pour un homme.

Je me suis étendue sur mon lit de février nue, dans une grande chemise plus pâle encore que la neige et faite pour un homme.

Je me suis étendue dans une grande chemise de neige faite pour un homme sur un lit nu et pâle de février

Je me suis étendue et j'ai songé longtemps à la fragilité de l'amour 
aux jours d'attente et d'incertitude

quand le temps se traîne

quand I'hiver devient plus tiède

quand le silence du soir nous monte à la gorge

quand nos berceuses ne nous endorment plus

quand nos rêves n'en finissent plus

de tourner infiniment

d'un bout à l'autre de la nuit

d'un bout à l'autre d'une pensée close...

et faite pour un homme.

Je me suis étendue

dans une grande chemise de février

et j'ai songé à l'intensité de l'amour.

Je me suis endormie en février

dans une grande chemise pâle faite pour un homme. 
Tandis que la saison encor est à son apogée et que déjà le printemps vient jouer dans nos tempes, dans nos hanches que les amants se sont éparpillés et perdus dans le froid la neige et le gel

Que les espoirs se sont refroidis et qu'il ne reste plus dans les chambrées qu'un lit incessamment calme et désert tel un pays fondé, habité et oublié

Nuits de rêveries maquillées, enroulées dans les draps du dimanche

et nues les autres jours du monde, étenderies infatiguables règnes de silences, de rires et de confusion 
Tirer un voile sur le baldaquin, dormir infiniment songer que l'océan viendra noyer les rêves que le ressac des vagues délèguera un mouvement infini à nos corps en écume des varechs à ma taille

du sable à nos épaules et du sel à nos lèvres.

Et là, agenouillés sur une plage blanche l'horizon et la mer alentour de nos âges tu m'embrasserais à la marée venante au profil de l'eau, presque échoués tous les deux au rivage tu me dirais tiens bien la voile et nous prendrions le large. 


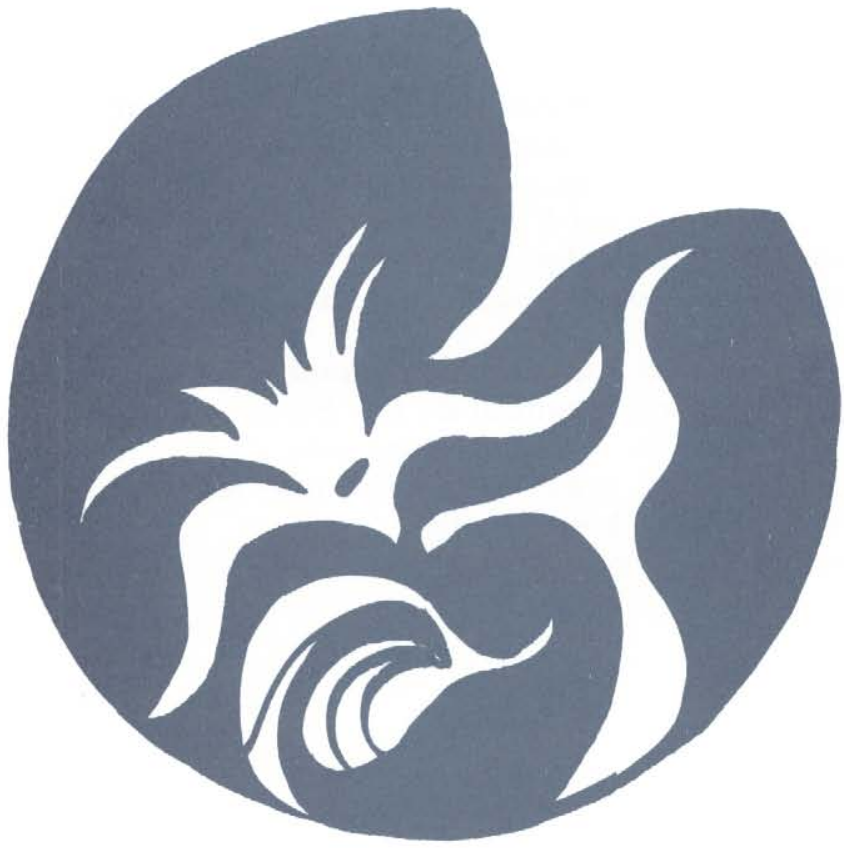

"Ce trou dans la neige comme une île enfoncée dans sa marée de glace."

(Somnolence) 